(c) American Dairy Science Association, 2004.

\title{
Peripartal Propylene Glycol Supplementation and Metabolism, Animal Health, Fertility, and Production in Dairy Cows
}

\author{
M. Hoedemaker, ${ }^{1}$ D. Prange, ${ }^{1}$ H. Zerbe, ${ }^{1}$ J. Frank, ${ }^{1}$ A. Daxenberger, ${ }^{2}$ and H. H. D. Meyer ${ }^{2}$ \\ ${ }^{1}$ Production Medicine Unit, Clinic for Cattle, School of Veterinary Medicine Hannover, Germany \\ ${ }^{2}$ Chair of Physiology, Technical University of Munich-Weihenstephan, Germany
}

\begin{abstract}
The effect of peripartal supplementation with concentrate enriched at $10 \%$ propylene glycol (PG) on metabolism, animal health, fertility, and milk production was studied using 234 cows from 8 dairy farms with production averages of 8019 to $10,656 \mathrm{~kg} / \mathrm{yr}$. The feeding schedule for the PG group ( $\mathrm{n}=117)$ was as follows: $13 \mathrm{~d}$ antepartum: $1.5 \mathrm{~kg} / \mathrm{d}$ (= $150 \mathrm{~mL} \mathrm{PG);12} \mathrm{d} \mathrm{antepartum}$ until parturition: $3 \mathrm{~kg} / \mathrm{d}$ (= $300 \mathrm{~mL} \mathrm{PG}) ; 1$ to $12 \mathrm{~d}$ postpartum: $1 \mathrm{~kg} / \mathrm{d}$ (= $100 \mathrm{~mL} \mathrm{PG)}$. Control cows $(\mathrm{n}=117)$ received the same concentrate without PG. From a subset of cows (PG: $n=43$; control: $n=40$ ), blood samples were collected at 6,3 , and $1 \mathrm{wk}$ antepartum, $3 \mathrm{~d}$ antepartum, on the day of parturition, and 1, 3, 5, 7, 9, and $11 \mathrm{wk}$ postpartum for the determination of nonesterified fatty acids (NEFA), $\beta$-hydroxybutyrate (BHBA), insulin-like growth factor (IGF)-I, and activities of aspartate-aminotransferase (AST) and glutamate-dehydrogenase (GLDH). From another subset of cows (PG: $\mathrm{n}=$ 11; control: $n=10)$, blood samples were collected 1 wk antepartum, on the day of parturition, and $1 \mathrm{wk}$ postpartum to determine immunophenotypical and functional parameters of blood neutrophils. From $1 \mathrm{wk}$ antepartum to $1 \mathrm{~d}$ postpartum, concentrations of NEFA were significantly lower in cows receiving $\mathrm{PG}$ compared with controls. Also, concentrations of BHBA in cows receiving $P G$ were significantly lower from 1 wk antepartum until 7 wk postpartum. Concentrations of IGFI were significantly higher in the PG group, from $1 \mathrm{wk}$ antepartum until 1 wk postpartum than in the control group. Activities of AST and GLDH did not differ between groups. Immunophenotypical and functional characteristics of blood neutrophils were not influenced by treatment nor were animal health, reproduction, or milk production. Although indicators of metabolic status were improved by peripartal use of PG-enriched concentrate, economic benefits are questionable for dairy farms with good nutritional programs, as econom-
\end{abstract}

Received August 6, 2003.

Accepted March 5, 2004.

Corresponding author: M. Hoedemaker; e-mail: Martina. Hoedemaker@tiho-hannover.de. ically important factors such as milk production, animal health, and fertility were not influenced.

(Key words: propylene glycol, metabolism, fertility, dairy cow)

Abbreviation key: AST = aspartate-aminotransferase, $\mathbf{G L D H}$ = glutamate-dehydrogenase, $\mathbf{m A B}=$ monoclonal antibodies, $\mathbf{P G}=$ propylene glycol, $\mathbf{P M N}=$ polymorphonuclear neutrophil, ROS = reactive oxygen species.

\section{INTRODUCTION}

During the transition period, which can be defined as the last $3 \mathrm{wk}$ before parturition to $3 \mathrm{wk}$ after parturition (Grummer, 1995), dairy cows are at an increased risk of a variety of health disorders such as metabolic and infectious diseases. These have a severe impact on further production and profitability of affected animals. Dry matter intake (DMI) of late pregnant cows may be markedly decreased and after parturition, DMI increase lags far behind the sudden increase of nutrient requirements (Bell, 1995). The resulting negative energy balance stimulates lipid mobilization from adipose tissues followed by a rise of NEFA concentrations in the blood and an increased uptake of NEFA by the liver. Extreme lipid mobilization exceeds the metabolizing capacity of the liver, leading to an increased triglyceride accumulation and formation of ketone bodies (Herdt, 1988). Associations between NEFA concentrations and incidence of ketosis, displaced abomasum, and retained fetal membranes have been described (Dyk et al., 1995). During the transition period, the immune system is suppressed, rendering the cow susceptible to infectious diseases such as mastitis and endometritis (Mallard et al., 1998). However, the mechanisms controlling DMI and the immunosuppression in the peripartal period as well as associations between metabolism and the immune system are not fully understood.

Transition cow programs aim at stabilizing and optimizing DMI and applying feeding strategies that provide a smooth transition from the pregnant, nonlactating state to the nonpregnant, lactating state. Furthermore, they include close monitoring of the transition 
cow and early treatment in case of any signs of disease as well as prophylactic treatments with glucose precursors and calcium (Drackley, 1999).

The glucogenic substance propylene glycol (PG) has been shown to decrease the negative effect of decreased DMI on negative energy balance (Studer et al., 1993; Formigoni et al., 1996) and to lower the risk of ketosis and fatty liver syndrome (Studer et al., 1993). However, little is known about the effects of PG supplementation in the transition period on health, fertility, and milk production, which are important factors to evaluate the profitability of this measurement.

Therefore, it was the aim of this study to investigate the effect of peripartal supplementation with PG mixed into concentrate on metabolism, neutrophil function, animal health, fertility, and milk production under field conditions involving dairy herds with a high milk production. Concentrate enrichment as the way of application was chosen because it had a higher acceptance by the dairy farmers than other ways of applications, such as drenching.

\section{MATERIALS AND METHODS}

\section{Cows and Experimental Design}

Two hundred thirty-four dairy cows from 8 different herds were included in this study. The average yearly milk yield of the herds was $9416 \mathrm{~kg}$ (range: 8019 to $10,656 \mathrm{~kg}$ ). The dairy herds were not considered as problem herds. They were selected because the PG supplementation during the transition period was to be tested as a prophylactic measure on the herd level in well-managed farms to further improve the well-being and health of the animals rather than a metaphylactic treatment in problem herds.

The diet of the lactating herd varied from farm to farm, but mainly consisted of grass silage, corn silage, and grass hay or straw with other ingredients such as beans, cereals, corn, rape meal, soybean meal, leguminose meal, sugar beet chips, and others. Furthermore, mineral mixtures with (5 farms) or without extra vitamins (3 farms) (the composition of which depended upon the main diet) were added. On 4 farms, the forage diet consisted of grass and corn silage. The other ingredients were supplied either via computerized feeding stations that quite often had 2 channels (one for concentrate; one for an additional component) or by hand. On the other 4 farms, the ingredients of the diet were mixed in a mobile feed mixer. The calculated DM of this basic diet ranged from 17.5 to $20.4 \mathrm{~kg} / \mathrm{d}$, and the energy density ranged from 6.37 to $6.94 \mathrm{MJ} \mathrm{NE}_{\mathrm{L}} / \mathrm{kg}$ of $\mathrm{DM}$, respectively. In addition, cows from all farms received commercially available concentrate $(6.7 \mathrm{MJ} \mathrm{NE} / \mathrm{kg} ; 18 \%$ $\mathrm{CP})$ via a computerized feeding station according to their milk production. On 6 farms, daily milk yield records were available. Those data were transferred to the feeding computer that adjusted the amount of concentrate for the individual cows based on the milk yield of mostly 3 or 4 consecutive milkings. Two farms used the data of the monthly DHI program and then adjusted the concentrate accordingly. The ration of the early dry cows consisted of grass silage and straw. Two weeks before the expected calving date, dry cows changed to the close-up group and were fed the basic diet of the lactating cows, however, without the milk yield-adjusted concentrate.

The dry cows were randomly distributed between 2 treatment groups. After they had changed from the early dry cow to the close-up group, one group $(\mathrm{n}=117)$ received commercially available concentrate (6.7 MJ $\mathrm{NE}_{\mathrm{L}} / \mathrm{kg} ; 18 \% \mathrm{CP}$ ) enriched with $10 \% \mathrm{PG}$ (BASF, Ludwigshafen, Germany). The PG-enriched concentrate was prepared at a commercial feed manufacturing facility. The PG was first adsorbed to sugar beet chips as a carrier and mixed into the concentrate, which then was pelleted. The other group of animals ( $n=117$; control) received the same concentrate without PG. The feeding schedule was as follows: d 13 antepartum, 1.5 $\mathrm{kg}$ of concentrate; d 12 antepartum until parturition, $3 \mathrm{~kg}$ of concentrate; and d 1 to 12 postpartum, $1 \mathrm{~kg}$ of concentrate (i.e., the PG group received daily amounts of 150,300 , and $100 \mathrm{~mL}$ of PG, respectively). Antepartum, 3 farms kept their dry cows in a stanchion barn or in individual boxes; 4 farms housed the dry cows in groups in a free stall with headlocks. The concentrate was given twice daily in the morning (0600 to $0800 \mathrm{~h}$ ) and evening (1700 to $1900 \mathrm{~h}$ ) usually before the rest of the diet was offered. Because all animals could be restrained, it was ensured that each animal received the correct amount of concentrate. On one farm, the concentrate was supplied via the computer feeder so that it could be consumed in small amounts during the day. Postpartum, the concentrate was offered in the milking parlor twice daily (6 farms). One farm used the computer feeder, and, on the remaining farm, cows were restrained via headlocks and fed individually twice daily. Only cows that calved within $6 \mathrm{~d}$ of the calculated calving date were included in this study.

From all experimental animals, calving, health, and reproductive records were collected. Blood samples were taken at 3 and $5 \mathrm{wk}$ postpartum for the determination of serum progesterone concentrations. In addition, milk production was evaluated using the data from the monthly milk quality control program.

From a subset of randomly selected cows (PG group: $n=43$; control group: $n=40$ ), blood samples were collected via the coccygeal vein: 6,3 , and $1 \mathrm{wk}$ antepartum, $3 \mathrm{~d}$ antepartum, on the day of parturition, and 1, 3, 5, 
7,9 , and $11 \mathrm{wk}$ postpartum for the determination of the serum concentrations of NEFA, $\beta$-hydroxybutyrate (BHBA), and insulin-like growth factor (IGF)-I and the activity of aspartate-aminotransferase (AST) and glutamate-dehydrogenase (GLDH). The serum was separated and stored at $-20^{\circ} \mathrm{C}$ until analysis. Blood samples were taken either in the morning or evening before feeding.

From another subset of randomly selected cows (PG group: $\mathrm{n}=11$; control group: $\mathrm{n}=10$ ), blood samples were taken from the vena coccygea using Vacutainer tubes (Becton Dickinson, Heidelberg, Germany) containing EDTA at 1 wk antepartum, on the day of parturition and at $1 \mathrm{wk}$ postpartum for the determination of neutrophilic parameters. On the day of blood sampling, blood samples were also collected from 3 ovariectomized reference animals.

\section{Assays for Blood Serum Constituents}

Serum progesterone concentrations were determined with radioimmunoassay according to Hamburger (1974). Intra- and interassay coefficients of variation were 6.6 and $8.0 \%$, respectively. Insulin-like growth factor-I was measured with a method developed by Daxenberger et al. (1998). The intra- and interassay coefficients of variation were 4.1 and $9.1 \%$, respectively.

Concentrations of NEFA and BHBA were determined via commercially available enzymatic test kits (NEFA: Wako, Neuss, Germany; BHBA: Sigma, Deisenhofen, Germany) according to Mulder et al. (1983) and McMurray et al. (1984).

Activities of AST and GLDH were measured using colorimetric assay kits (Roche Diagnostics $\mathrm{GmbH}$, Mannheim, Germany) according to DGKC (1972). The intraassay coefficients of variations for NEFA, BHBA, AST, and GLDH were $4.2,3.8,1.2$, and $1.2 \%$, respectively.

\section{Characterization of Immunophenotypical and Functional Traits of Blood Neutrophils}

Bovine polymorphonuclear neutrophils (PMN) were isolated as previously described (Zerbe et al., 1996) using density gradient centrifugation on Percoll (Pharmacia, Freiburg, Germany) following hypotonic lysis of erythrocytes. Isolated cells were adjusted to $2 \times 10^{6}$ leukocytes/mL (PMN purity $>95 \%$, viability $>95 \%$ ) for in vitro characterization.

The total leukocyte concentration was determined in a cell-counting chamber after staining with Turk's solution (Merck, Darmstadt, Germany). Differential counts were determined by flow cytometry (FACScan; Becton Dickinson, Heidelberg, Germany) after counting of at least 3000 leukocytes.
Immunophenotypical characteristics of PMN were evaluated according to a method previously described for bovine PMN (Zerbe et al., 1996) using flow cytometry. The primary bovine-specific monoclonal antibodies (mAB) were mAB IL-A15 for detecting BoCD11b/CD18 and mAB IL-A99 for detecting BoCD11a/CD18 (Naessens and Hopkins, 1996).

The generation of reactive oxygen species (ROS) was measured according to Emmendörffer et al. (1990) using flow cytometry. The PMN were stimulated with phorbol myristate acetate (300 nmol/L; Sigma, Deisenhofen, Germany) and then loaded with the nonfluorescent dye dihydrorhodamin $123(15 \mu \mathrm{g} / \mathrm{mL}$; Morbitec, Göttingen, Germany), which, in the presence of ROS generation, was converted into the green fluorescent rhodamin 123 via oxidation catalyzed by cellular myeloperoxidase.

The phagocytic activity was determined according to a method previously described by Zerbe et al. (2001) using commercially available nonviable Streptococcus zooepidemicus suspension (Omnisorbin; Calbiochem, Bad Soden, Germany) labeled with FITC (Sigma, Deisenhofen, Germany).

The means obtained with PMN of the 3 ovariectomized reference animals were set at $100 \%$, and the final results for the experimental animals were expressed as a percentage of the reference value.

\section{Analysis of Milk Composition}

During monthly DHI testing, milk production and milk constituents, such as fat, protein, lactose, and urea as well as SCC in whole milk samples, were determined for each lactating cow. Composite milk samples were collected during the morning and evening milking, mixed, and analyzed in the regional DHI laboratory using the infrared spectrophotometer MilkoScan 4000 (Foss Electrec, Denmark). The fat, protein, and lactose contents were determined according to Rudzik (1981), and the urea content was determined according to Rahmatullah and Boyd (1980). The first 4 test $d$ were included in the analysis. As the number of days in milk on the single test days differed from cow to cow, the individual cow data were broken into 4 time periods: period $1, \mathrm{~d} 5$ to 30 postpartum; period 2 , d 31 to 62 postpartum; period 3, d 63 to 93 postpartum; and period 4, d 94 to 125 postpartum. The 100-d and peak milk yields were calculated according to Wood (1967) and Schneeberger (1978).

\section{Reproductive Performance and Health Data}

Fertility was assessed using the following measures: first service conception rate $=$ number of cows pregnant 
after first $\mathrm{AI}$ in relation to the total number of cows inseminated (\%); overall pregnancy rate $=$ number of pregnant cows in relation to number of inseminated cows $(\%)$; conception rate $=$ number of successful $\mathrm{AI}$ in relation to the total number of $\mathrm{AI}(\%)$; pregnancy index = number of AI in animals that eventually became pregnant/number of pregnant animals. Days was the unit of measure for interval from calving to first AI, interval from first AI to conception and days open (interval from calving to conception). The overall culling rate and the culling rate because of infertility were also calculated.

Farm records gave information about the incidence of dystocia, retained placental fetal membranes, endometritis, milk fever, displaced abomasum, mastitis, lameness, and other diseases.

\section{Statistical Analyses}

All data sets were checked for normal distribution. Statistical analyses were performed applying standard statistical procedures (Steel and Torrie, 1980) and using the computer program SAS (1991). In case a normal distribution could not be verified (NEFA, BHBA, IGF-I, AST, GLDH, and reproductive measures), means were compared with non-parametric analysis (NPAR1WAY procedure; SAS, 1991). To study the temporal pattern of metabolic variables, the sampling points at $6 \mathrm{wk}$ antepartum and on the day of parturition were compared with following time points. For normally distributed data, a 2-factorial ANOVA with repeated measurements was used (PROC MIXED procedure; SAS, 1991). For the analysis of milk composition data and neutrophil function, the factors were treatment (PG vs. control) and time periods (repeated measures). Also treatment $\times$ time interactions were examined. Somatic cell count data were log-transformed and subjected also to the 2-factorial ANOVA with repeated measurements. When only 2 means were compared, Student's $t$-test was applied. Frequencies were compared with the $\chi^{2}$ test. Data in the table and graphs are expressed as means \pm standard errors of the means or frequencies (\%). The level of significance was set at $P<0.05$.

\section{RESULTS}

\section{Serum Metabolites}

Mean NEFA concentrations of the PG group were lower at $1 \mathrm{wk}$ and $3 \mathrm{~d}$ antepartum and on the day of parturition than in the control group $(P<0.05)$ (Figure 1). In both groups, mean NEFA concentrations increased at parturition and then continuously declined until the end of the study period $(P<0.05)$. Mean BHBA concentrations in the PG group were lower from $1 \mathrm{wk}$ antepartum until 7 wk postpartum (Figure 1). Statisti-
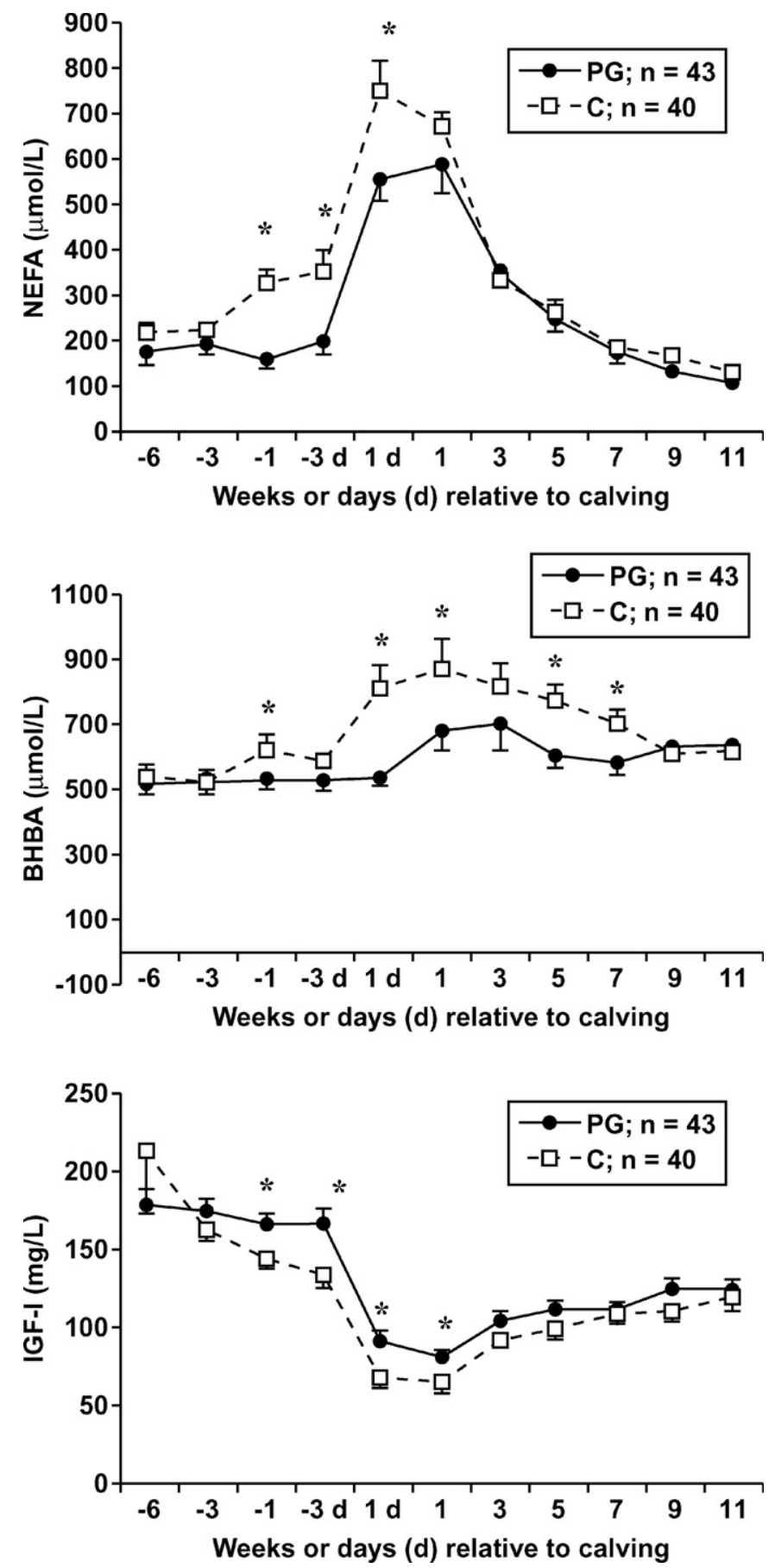

Figure 1. Mean serum concentration \pm SEM of NEFA, BHBA, and IGF-I in cows receiving concentrate supplemented with $10 \%$ propylene glycol (PG; $)$ or concentrate only $(\mathrm{C} ; \square)$ from $13 \mathrm{~d}$ antepartum until $12 \mathrm{~d}$ postpartum. ${ }^{*} \mathrm{PG}$ vs. $\mathrm{C}(P<0.05)$.

cally significant group differences were detected $1 \mathrm{wk}$ antepartum, on the day of parturition, and 1, 5, and 7 wk postpartum $(P<0.05)$. In both groups, mean BHBA concentrations increased in the periparturient period. 
However, compared with the beginning of the study period ( 6 wk antepartum), mean BHBA concentrations increased earlier $(P<0.05)$ in the control group $(1 \mathrm{wk}$ antepartum) than in the PG group (1 wk postpartum). In the control group, mean BHBA concentrations decreased from the day of parturition until wk $9(P<$ 0.05), whereas in the PG group the BHBA concentrations were slightly higher in the postpartal study period than on the day of parturition $(P<0.05)$. From $1 \mathrm{wk}$ antepartum until 11 wk postpartum, the BHBA threshold of $1000 \mu \mathrm{mol} / \mathrm{L}$ was exceeded at least once more often in the control group than in the PG group (60.0\% of control cows vs. $25.6 \%$ of PG treated cows, respectively; $P<0.05$ ). In the PG group, mean IGF-I concentrations were higher from $1 \mathrm{wk}$ antepartum until $1 \mathrm{wk}$ postpartum compared with the control group $(P<0.05)$ (Figure 1). Whereas the mean IGF-I concentrations in the PG group did not differ throughout the dry period, but decreased at parturition, in the control group, a significant decrease in IGF-I concentrations was noted already at $1 \mathrm{wk}$ antepartum $(P<0.05)$. In both groups, mean IGF-I concentrations remained lower throughout the postpartal study period than during the dry period $(P<0.05)$. Compared with the day of parturition, mean IGF-I concentrations slightly increased again at wk 5 $(\mathrm{PG})$ or wk 3 (control) $(P<0.05)$. No group differences were observed for the activity of AST (Figure 2). In both groups, mean activity of AST increased from 6 wk antepartum until the day of parturition and then remained on a lower level from 3 wk postpartum onward $(P<0.05)$. No group differences were observed for the activity of GLDH (Figure 2), except for $9 \mathrm{wk}$ postpartum, when the mean activities of GLDH were sligthly higher in the PG group than in the control group (12.7 \pm 1.9 vs. $10.8 \pm 1.7$, respectively; $P<0.05$ ).

\section{Progesterone Concentrations}

Progesterone concentrations of $>3.18 \mathrm{nmol} / \mathrm{L}$ were considered as indicators of the presence of active luteal tissue and, therefore, the resumption of the ovarian cycle. By 3 wk postpartum, luteal function was detected in $47.9 \%$ of the PG-treated animals and in $43.6 \%$ of the control animals $(P=0.512)$. Thirty-five of the PGtreated animals (29.9\%) and 31 of the control animals (26.5\%) did not have ovarian cyclicity by 5 wk postpartum $(P=0.561)$.

\section{Numbers, Phenotype, and Functional Capacity of Neutrophils}

The mean total leukocyte concentration in the blood of PG-treated and control animals ranged from 5.9 to 7.8 $\times 10^{6}$ leukocytes $/ \mathrm{mL}$ and did not differ between groups.
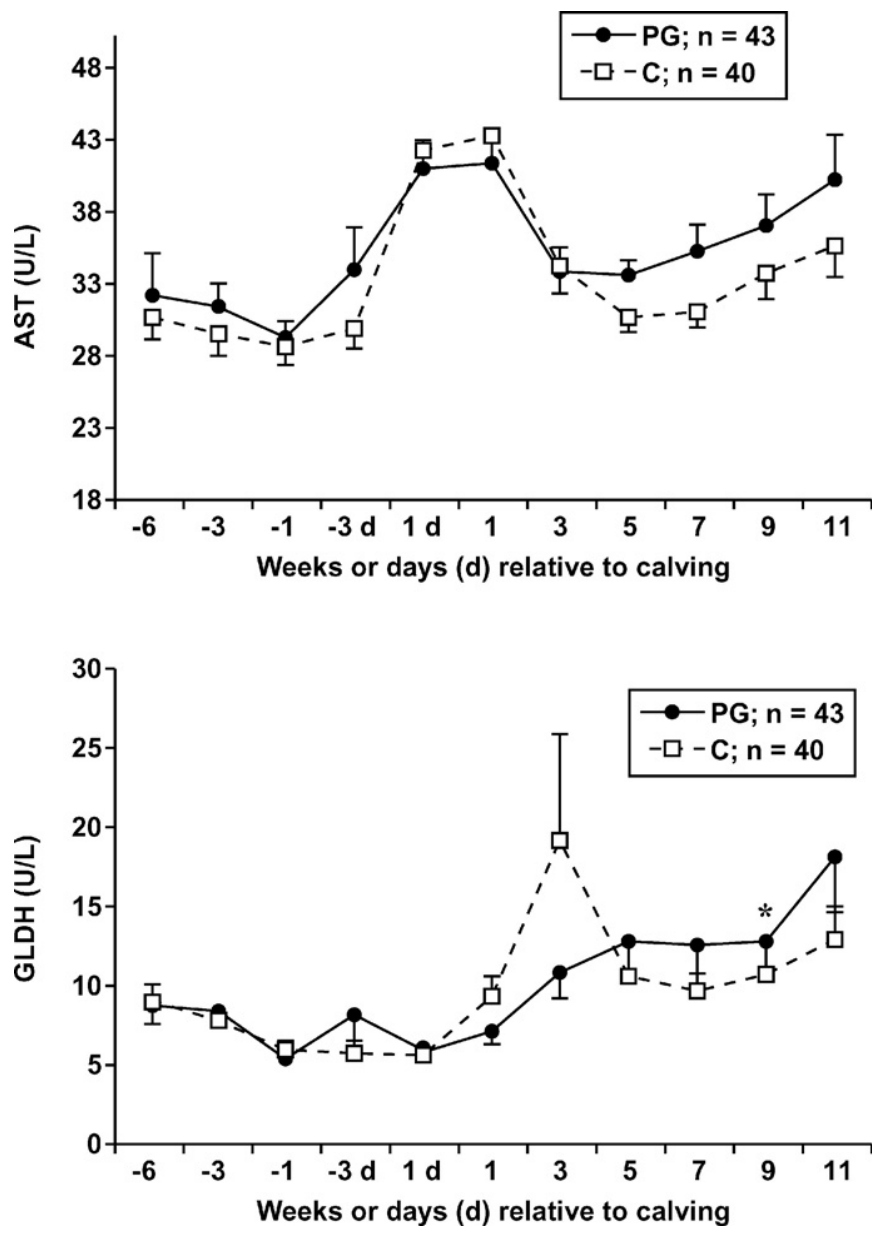

Figure 2. Mean serum activities \pm SEM of aspartate-aminotransferase (AST) and glutamate-dehydrogenase (GLDH) in cows receiving concentrate supplemented with $10 \%$ propylene glycol (PG; $)$ or concentrate only $(\mathrm{C} ; \square)$ from $13 \mathrm{~d}$ antepartum until $12 \mathrm{~d}$ postpartum. *PG vs. $\mathrm{C}(P<0.05)$.

Furthermore, there were no group differences with regard to the differential counts (data not shown) $(P>$ $0.05)$.

No treatment and time effects or treatment $\times$ time interactions were noted for the immunophenotypical (receptor expression of CD11a and CD11b) and functional characteristics (phagocytosis, ROS generation) of PMN. The mean relative receptor expression of CD11a and CD11b (PG vs. control group) was $88.3 \pm$ $4.0 \%$ vs. $93.9 \pm 3.7 \%(P=0.298)$ and $90.6 \pm 3.7 \%$ vs. $99.6 \pm 4.6 \%(P=0.139)$, respectively. The mean relative phagocytosis and ROS generation (PG vs. control group) was $102.7 \pm 2.8 \%$ vs. $106.5 \pm 2.3 \%(P=0.257)$ and 58.4 $\pm 5.3 \%$ vs. $48.8 \pm 5.3 \%(P=0.219)$, respectively.

\section{Animal Health Data and Culling Rate}

The incidence of diseases did not differ between the PG and control groups. The following incidences were 


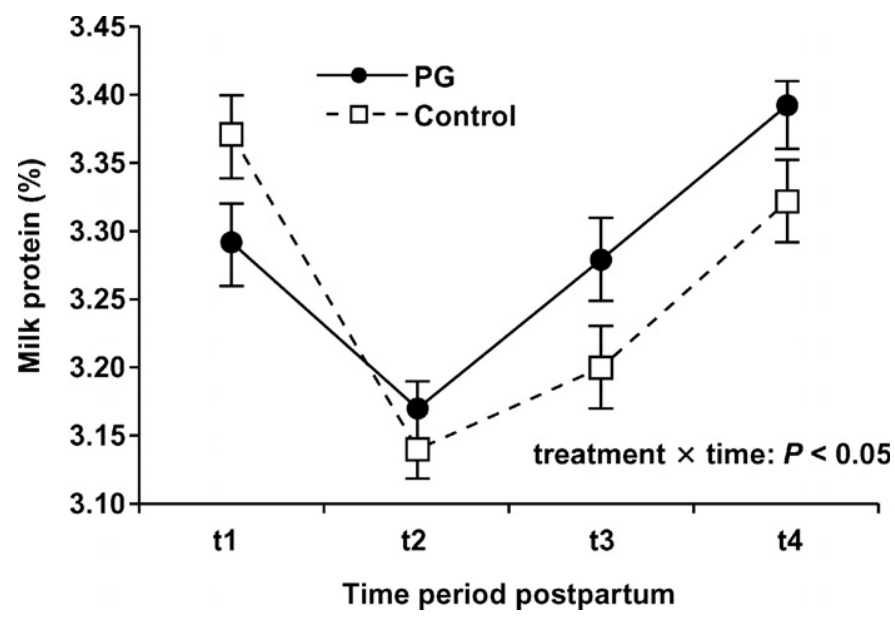

Figure 3. Mean \pm SEM test day milk protein percentage during 4 periods ( $\mathrm{t} 1=5$ to $30 \mathrm{~d}$ postpartum, $\mathrm{t} 2=31$ to $62 \mathrm{~d}$ postpartum, $\mathrm{t} 3=63$ to $93 \mathrm{~d}$ postpartum, and $\mathrm{t} 4=94$ to $125 \mathrm{~d}$ postpartum) from cows receiving concentrate supplemented with $10 \%$ propylene glycol (PG; O) or concentrate only (C; $\square$ ) from $13 \mathrm{~d}$ antepartum until 12 d postpartum.

found (PG vs. control group): dystocia (12.9\% vs. $15.4 \%$; $P=0.573)$, retained placental fetal membranes $(13.7 \%$ vs. $17.1 \% ; P=0.467)$, milk fever $(11.1 \%$ vs. $9.4 \% ; P=$ $0.667)$, puerperal endometritis $(43.5 \%$ vs. $49.6 \% ; P=$ $0.359)$, ovarian cysts $(15.4 \%$ vs. $12.8 \% ; P=0.573)$, clinical mastitis ( $39.3 \%$ vs. $34.2 \% ; P=0.416)$, displaced abomasum $(1.7 \%$ vs. $3.4 \% ; P=0.683)$, lameness $(27.4 \%$ vs. $24.8 \% ; P=0.655$ ), other (respiratory tract diseases, eye or skin diseases, reticuloperitonitis: $8.5 \%$ vs. $13.7 \%$; $P=0.212$ ). Mean $\log _{10}$ milk SCC did not differ between groups (PG vs. control: $4.98 \pm 0.02$ vs. $4.97 \pm 0.02 / \mathrm{mL}$, respectively; $P=0.961$ ) and did not change over time. Culling rate was $23.1 \%$ in the PG group and $29.2 \%$ in the control group and did not differ between groups $(P=0.297)$.

\section{Measures of Fertility}

Measures of fertility did not differ between the 2 treatment groups. In the PG group, 104 of 117 animals were inseminated; 76 became pregnant. In the control group, 101 of 117 cows were inseminated, of which 72 became pregnant. Accordingly, the first service conception rate, the conception rate, the overall pregnancy rate, and the mean pregnancy index in the PG vs. the control group were $39.4 \%$ vs. $38.6 \%(P=0.576), 39.4 \%$ vs. $36.0 \%(P=0.490), 73.1 \%$ vs. $71.3 \%(P=0.775)$, and $1.74 \pm 0.20$ vs. $1.78 \pm 0.21(P=0.857)$, respectively. The mean interval from calving to first AI, interval from first AI to conception, and days open in the PG vs. the control group were $89.2 \pm 3.3$ vs. $88.6 \pm 3.3 \mathrm{~d}(P=0.998)$, $26.2 \pm 4.0$ vs. $28.9 \pm 4.7 \mathrm{~d}(P=0.686)$, and $110.0 \pm$
4.2 vs. $110.6 \pm 4.9 \mathrm{~d}(P=0.842)$, respectively. Culling because of infertility was $12.8 \%$ in the PG group and $17.1 \%$ in the control group and did not differ between groups $(P=0.359)$.

\section{Milk Yield and Milk Constituents}

Mean 100-d milk yields in the PG and control groups were $3641 \pm 79$ and $3540 \pm 73 \mathrm{~kg}$, respectively, and did not differ between groups $(P=0.349)$. Furthermore, there was no group difference in the mean peak milk yield (PG vs. control: $33.8 \pm 0.7$ vs. $34.5 \pm 0.6 \mathrm{~kg}$, respectively; $P=0.449$ ). No group differences were detected for milk yield or for various milk constituents. However, significant time effects indicated an increase in mean milk yield from period 1 to period 2 followed by declines in periods 3 and 4 after peak production was reached (Table 1). Mean fat yields in kilograms continuously decreased from period 1 through period 4. Mean fat percentage decreased from period 1 to period 2 and slightly increased again by period 4 . Mean protein yields in kilograms did not change over time. Mean protein percentage decreased from period 1 to period 2 and then increased in periods 3 and 4 . A significant treatment $\times$ time interaction revealed a higher protein content for controls during period 1 , which then decreased and was lower than in the PG group for periods 2 to 4 (Figure 3). Mean lactose yields in kilograms increased from period 1 to period 2 and then decreased again in periods 3 and 4 . Mean lactose percentage did not change over time. Mean milk urea concentration increased from period 1 to period 4 .

\section{DISCUSSION}

Sequential changes of pre- and postpartal serum concentrations of NEFA, BHBA, IGF-I, and activities of AST and GLDH found in this field study were similar to those reported by other authors (Studer et al., 1993; Horvat and Jovanovic, 1999; Bremmer et al., 2000). Application of $P G$ via enriched concentrate during the last $13 \mathrm{~d}$ antepartum and the first $12 \mathrm{~d}$ postpartum diminished the prepartal rise in concentrations of NEFA and BHBA. This effect was observed shortly after the beginning of $\mathrm{PG}$ supplementation, i.e., at the sampling point $1 \mathrm{wk}$ antepartum, indicating that this type of PG supplementation might be a proper way to rapidly decrease lipid mobilization and excessive formation of ketone bodies, thereby reducing the risk of fatty liver and ketosis. A decrease in NEFA following PG application during the transition period was also reported in previous studies (Studer et al., 1993; Formigoni et al., 1996) and in short-term studies applying a 2- or 3dimensional oral drench of PG (Pickett et al., 2003). 
Table 1. Mean \pm SEM test day milk (kg), fat (kg, \%), protein $(\mathrm{kg}, \%)$, lactose $(\mathrm{kg}, \%)$, and urea concentration $(\mathrm{mmol} / \mathrm{L})$ during 4 postpartum periods $(\mathrm{t} 1=\mathrm{d} 5$ to $30, \mathrm{t} 2=\mathrm{d} 31$ to $62, \mathrm{t} 3=\mathrm{d} 63$ to 93 , and $\mathrm{t} 4=\mathrm{d} 94$ to 125$)$. Data of the experimental and control animals were pooled.

\begin{tabular}{lllll}
\hline Milk constituent & $\mathrm{t} 1$ & $\mathrm{t} 2$ & $\mathrm{t} 3$ & $\mathrm{t} 4$ \\
\hline Milk, kg & $35.1 \pm 0.6^{\mathrm{a}}$ & $37.3 \pm 0.6^{\mathrm{b}}$ & $35.1 \pm 0.5^{\mathrm{a}}$ & $33.2 \pm 0.5^{\mathrm{a}}$ \\
Fat, kg & $1.52 \pm 0.03^{\mathrm{a}}$ & $1.43 \pm 0.03^{\mathrm{a}, \mathrm{c}}$ & $1.40 \pm 0.02^{\mathrm{b}, \mathrm{c}}$ & $1.33 \pm 0.02^{\mathrm{b}}$ \\
Fat, \% & $4.38 \pm 0.05^{\mathrm{a}}$ & $3.88 \pm 0.04^{\mathrm{b}}$ & $4.02 \pm 0.04^{\mathrm{b}, \mathrm{d}}$ & $4.07 \pm 0.04^{\mathrm{c}, \mathrm{d}}$ \\
Protein, kg & $1.16 \pm 0.02^{\mathrm{a}}$ & $1.17 \pm 0.02^{\mathrm{a}}$ & $1.13 \pm 0.02^{\mathrm{a}}$ & $1.11 \pm 0.02^{\mathrm{a}}$ \\
Protein, \% & $3.33 \pm 0.02^{\mathrm{a}}$ & $3.16 \pm 0.02^{\mathrm{b}}$ & $3.24 \pm 0.02^{\mathrm{c}}$ & $3.36 \pm 0.02^{\mathrm{a}}$ \\
Lactose, kg & $1.68 \pm 0.03^{\mathrm{a}}$ & $1.80 \pm 0.03^{\mathrm{b}}$ & $1.69 \pm 0.03^{\mathrm{a}}$ & $1.59 \pm 0.02^{\mathrm{a}}$ \\
Lactose, \% & $4.79 \pm 0.01^{\mathrm{a}}$ & $4.83 \pm 0.01^{\mathrm{a}}$ & $4.82 \pm 0.02^{\mathrm{a}}$ & $4.80 \pm 0.01^{\mathrm{a}}$ \\
Urea, $\mathrm{mmol} / \mathrm{L}$ & $3.90 \pm 0.06^{\mathrm{a}}$ & $4.04 \pm 0.05^{\mathrm{a}, \mathrm{c}}$ & $4.02 \pm 0.05^{\mathrm{a}}$ & $4.22 \pm 0.05^{\mathrm{b}, \mathrm{c}}$ \\
\hline
\end{tabular}

${ }^{\mathrm{a}, \mathrm{b}, \mathrm{c}, \mathrm{d}}$ Within rows, means with different letter superscripts are statistically significantly $(P<0.05)$.

With regard to BHBA, it is of interest to note that concentrations of BHBA in the control group remained higher than in the PG group until wk 7 postpartum, although PG supplementation was only conducted until d 12 postpartum. Furthermore, frequency of cows with subclinical ketosis was significantly lower in the PG group than in the control group. This could be interpreted as a carry-over effect of the PG-induced decrease in NEFA release and subsequent ketone body formation. Other studies also reported decreased BHBA concentrations under various experimental settings (Studer et al., 1993; Grummer et al., 1994), whereas other research groups were not able to find an effect of PG on BHBA concentrations (Formigoni et al., 1996; Pickett et al., 2003).

Activities of AST and GLDH were not affected by PG administration. The determination of activity of both enzymes was recommended as part of a metabolic profile test to monitor the health status of the liver (Lotthammer, 1981). A temporal increase in activity of AST, which was also observed in our study, was described during the first 2 wk postpartum (Sommer, 1969). This transitory increase was interpreted not as a pathological condition, but rather as an adjustment of liver cell turnover rate to the increased metabolic demands during late pregnancy and early lactation (Bostedt, 1974). In our study, the mean activities of AST, even during the time period of elevated activities, were within normal range (Lotthammer, 1981). Although lipid mobilization and cases of transitory subclinical ketosis occurred, these apparently did not lead to measurable liver damage based on AST activities. However, activities of GLDH slowly increased beyond the threshold level of $10 \mathrm{U} / \mathrm{L}$ as lactation progressed, indicating some degree of liver damage. Increased activity of GLDH is considered as an indicator of chronic liver damage occurring often 3 to $5 \mathrm{wk}$ following the rise in AST activity (Wemheuer, 1987). In our study, this development was not influenced by the peripartal supplementation with PG. It could be speculated whether a pro- longed supplementation with PG might have prevented the rise in GLDH activity. Overall, the value of determination of activities of AST and GLDH as indicators of liver health especially in cows without clinical signs seems to be of limited value. This might be because variation in enzyme activity (e.g., GLDH) is too low to differentiate between normal and either mild or moderate abnormal liver function (Albrecht and Unglaub, 1992) or that there are inconsistent results when blood metabolites including enzyme activities (e.g., AST) are attributed to the liver status based on, for example, liver fat (Sevinc et al., 2001).

Serum concentrations of IGF-I sharply decreased around parturition. However, in the control group, this decrease occurred earlier (1 wk antepartum) than in the PG group (at parturition), and mean IGF-I concentrations were higher in the PG group than in the control group from $1 \mathrm{wk}$ antepartum until $1 \mathrm{wk}$ postpartum. A peripartal decrease in IGF-I concentrations was also reported in previous studies (Formigoni et al., 1996). Administration of PG during the transition period also had a positive effect on IGF-I concentrations, but, in contrast to our study, higher concentrations of IGF-I in the treated vs. the control group were detected in the postpartal period (Formigoni et al., 1996). It was found that negative energy balance has a negative effect on IGF-I concentrations (Lucy et al., 1992), which would explain the decrease in IGF-I concentration around parturition. Insulin-like growth factor-I belongs to the IGF superfamily, and the synthesis of most components of the IGF system is regulated through nutrition (Thissen et al., 1994). The primary source of IGF-I is the liver, but it is also synthesized in many tissues including reproductive tissues such as granulosa cells, oviductal cells, endometrium, and placenta (Spicer et al., 1993; Sharma et al., 1994; Wathes et al., 1998). Therefore, IGF-I in connection with other IGF and its binding proteins acting in an endocrine and paracrine or autocrine manner could be the link between nutrient and metabolic status and reproduction. In fact, it was shown 
that cows in a negative energy balance had lower plasma IGF-I concentrations in connection with reduced luteal activity, slower follicular growth, and altered steroid production (Spicer et al., 1990; Lucy et al., 1992).

Although the metabolic data from the subset of cows revealed a clear effect of PG supplementation on lipid mobilization, ketone body formation, and systemic IGFI concentrations, which documents a reduced metabolic stress during the transition period, no long-term effect was seen on animal health, fertility, or productivity. The disease frequency reported in this study was high, and it is surprising that clinical ketosis, as a separate disease, was not diagnosed. However, this finding along with low prevalence of displaced abomasum of 2 to $3 \%$ indicate overall good feeding management of the participating farms. At this point, it cannot be excluded that a secondary ketosis might have accompanied the other diseases found in this study, although it was not diagnosed as such. A previous study applying a similar administration schedule of PG also noted no effect on animal health (Formigoni et al., 1996). However, those researchers found an effect of PG on the frequency of anestrous cows: by $40 \mathrm{~d}$ postpartum, $80 \%$ of cows in treated and control groups were anestrous; by $90 \mathrm{~d}$ postpartum, only $30 \%$ of the PG-treated animals were anestrous compared with $58 \%$ of control animals $(P<$ $0.01)$. In contrast, no group differences on estrous cycles were evident in the current study. Based on progesterone concentrations at 3 and $5 \mathrm{wk}$ postpartum, fewer cows were acyclic $(\sim 30 \%)$ by $5 \mathrm{wk}$ postpartum in the current study than reported by Formigoni et al. (1996). By wk 3 postpartum, approximately $45 \%$ of all cows had resumed estrous cycles. In another study, PG drenches were given from 7 to $42 \mathrm{~d}$ of lactation (Miyoshi et al., 2001). It was reported that first ovulation occurred earlier in the treated cows than in the control cows. Furthermore, the first luteal phase was longer in the treated cows than in the control cows. However, in agreement with our results, no effect was seen on other reproductive measures. Miettinen (1995) administered a glycogenic drench containing 50\% PG and other substances from 14 to $24 \mathrm{~d}$ postpartum and were unable to improve fertility in treated cows compared with control cows. Pehrson et al. (1992) supplied an energy mixture containing soybean meal, beet pulp, glycerol, and calcium propionate (3.25 Mcal of metabolizable energy/d) from $40 \mathrm{~d}$ postpartum until first insemination or $75 \mathrm{~d}$ of lactation and observed a shorter interval from calving to last insemination. The reason for the lack of effect of PG supplementation in the present study might be that the dairy farms participating in the experiment had relatively high production, which can only be achieved with an excellent animal and feeding manage- ment. In well-managed dairy farms with an apparently effective nutritional and transition cow program, most cows are likely to cope with the negative energy balance postpartum without becoming sick or having fertility problems. Therefore, use of PG supplementation might not be as effective in such herds in improving health and fertility measures.

The same might be true for the properties and function of neutrophil leukocytes, which did not differ between PG-treated and control animals. Based on other investigations, it could have been expected that the improved metabolic status of the PG-treated animals (lower NEFA and BHBA concentration) might have enhanced leukocyte capacity. For instance, ketone bodies have been shown to inhibit phagocytic activity of bovine milk and blood PMN (Klucinski et al., 1988). Furthermore, mitogen-induced lymphocyte blastogenesis in cows with glucose deficiency or during ketosis was reduced (Franklin et al., 1991; Sato et al., 1995). Experimental fatty liver coincided with a reduced expression of function-associated surface molecules on blood neutrophils (e.g., CD11b/CD18 = CR3 and CD11c/CD18 = CR4), a diminished antibody-dependent and -independent cellular cytotoxicity, as well as ROS generation (Zerbe et al., 2000).

Milk yield and milk constituents did not differ between PG-treated and control cows. Only a significant group $\times$ treatment interaction for milk protein percentage suggested a slightly better energy status of the treated cows compared with the control animals. In agreement with our results, no effect of PG treatment on milk yield, milk protein percentage, and milk fat percentage was found in previous studies (Pehrson et al., 1992; Formigoni et al., 1996; Miyoshi et al., 2001). In contrast, Miettinen (1995) reported higher milk yield on the second test day in the treated group than in the control group. However, milk yield on the first test day as well as milk protein and fat percentage and annual milk yield did not differ between groups. Milk yield and milk constituents are most affected by nutrition, but can also be influenced by other factors such as genetics, parity, season, and disease status. On farms with a good nutritional program, those factors might override a possible effect of $\mathrm{PG}$.

\section{CONCLUSIONS}

In conclusion, although a positive effect of peripartal supplementation with PG on metabolism was observed, this did not translate into a long-term improvement of animal health, reproduction, or productivity compared with the control group. Because those factors that potentially affect the profit of a dairy farm did not differ significantly between groups, supplementation with PG 
might not be economically justified on farms similar to those in this study, as returns would not cover the costs of $\$ 12.00$ to $\$ 18.00$ per cow. It is not known whether a more beneficial response to PG might have been attained among cows on lower planes of nutrition or otherwise less optimally managed.

\section{ACKNOWLEDGMENTS}

We thank BASF (Ludwigshafen, Germany) for the kindly supply of PG. Characterization of neutrophil function was supported by the H.-Wilhelm-Schaumann Foundation.

\section{REFERENCES}

Albrecht, E., and W. Unglaub. 1992. Zur Anwendung der GLDHBestimmung in Rinderproblembetrieben. Tierärztl. Umschau. 47:427-430.

Bell, A. W. 1995. Regulation of organic nutrient metabolism during transition from late pregnancy to early lactation. J. Anim. Sci. 73:2804-2819.

Bostedt, H. 1974. Enzymaktivitäten im Blutserum von Rindern in der Zeit um die Geburt. Berl. Münch. Tierärztl. Wochenschr. 87:356-371.

Bremmer, D. R., S. J. Bertics, S. A. Besong, and R. R. Grummer. 2000. Changes in hepatic microsomal triglyceride transfer protein and triglyceride in periparturient dairy cattle. J. Dairy Sci. 83:2252-2260.

Daxenberger, A., B. H. Breier, and H. Sauerwein. 1998. Increased milk levels of insulin-like growth factor-I (IGF-I) for the identification of bovine somatotropin (bST) treated cows. Analyst 123:2429-2435.

DGKC (Deutsche Gesellschaft für Klinische Chemie). 1972. Empfehlungen der Deutschen Gesellschaft für Klinische Chemie (DGKC). J. Clin. Chem. Clin. Biochem. 10:182-193.

Drackley, J. K. 1999. Biology of dairy cows during the transition period: The final frontier? J. Dairy Sci. 82:2259-2273.

Dyk, P. B., R. S. Emery, J. L. Liesman, H. F. Bucholtz, and M. J. Vandehaar. 1995. Prepartum non-esterified fatty acids in plasma are higher in cows developing periparturient health problems. J. Dairy Sci. 78(Suppl. 1):264. (Abstr.)

Emmendörffer, A., M. Hecht, M. L. Lohmann-Matthes, and J. Roesler. 1990. A fast and easy method to determine the production of reactive oxygen intermediates by human and murine phagocytes using dihydrorhodamin 123. J. Immunol. Method. 131:269-275.

Formigoni, A. M., C. Cornil, A. Prandi, A. Mordenti, A. Rossi, D. Portetelle, and R. Renaville. 1996. Effect of propylene glycol supplementation around parturition on milk yield, reproduction performance and some hormonal and metabolic characteristics in dairy cows. J. Dairy Res. 63:11-24.

Franklin, S. T., J. W. Young, and B. J. Nonnecke. 1991. Effects of ketones, acetate, butyrate, and glucose on bovine lymphocyte proliferation. J. Dairy Sci. 74:2507-2514.

Grummer, R. R. 1995. Impact of changes in organic nutrient metabolism on feeding the transition dairy cow. J. Anim. Sci. 73:2820-2833.

Grummer, R. R., J. C. Winkler, S. J. Bertics, and V. A. Studer. 1994. Effect of propylene glycol dosage during feed restriction on metabolites in blood of prepartum Holstein heifers. J. Dairy Sci. 77:3618-3623.

Hamburger, R. 1974. Progesteronbestimmung in der Milch. Ph.D. Diss., Technische Universität München, Germany.

Herdt, T. H. 1988. Fatty liver in dairy cows. Vet. Clin. North Am. Food. Anim. Pract. 4:269-287.

Horvat, J., and M. Jovanovic. 1999. The concentration of total bilirubin and activity of AST, ALT, GLDH, CPK and AP in the blood of cows before and after calving. Acta Vet. Beograd. 49:2-3.
Klucinski, W., A. Degorski, E. Miernik-Degorska, S. Targowski, and A. Winnicka. 1988. Effect of ketone bodies on the phagocytic activity of bovine milk macrophages and polymorphonuclear leukocytes. J. Vet. Med. A 35:632-639.

Lotthammer, K.-H. 1981. Gesundheits- und Fruchtbarkeitsstörungen beim Milchrind. Klinisch-chemische Untersuchungen als Hilfsmittel zur Herdendiagnostik (Klärung der Ursachen). Tierärztl. Praxis. 9:541-551.

Lucy, M. C., J. Beck, C. R. Staples, H. H. Head, R. L. De La Sota, and W. W. Thatcher. 1992. Follicular dynamics, plasma metabolites, hormones and insulin-like growth factor 1 (IGF-I) in lactating cows with positive or negative energy balance during the preovulatory period. Reprod. Nutr. Dev. 32:331-341.

Mallard, B. A., J. C. Dekkers, M. J. Ireland, K. E. Leslie, S. Sharif, C. Lacey Vankampen, L. Wagter, and B. N. Wilkie. 1998. Alteration in immune responsiveness during the peripartum period and its ramification on dairy cow and calf health. J. Dairy Sci. 81:585-595.

McMurray, C. H., W. J. Blanchflower, and D. A. Rice. 1984. Automated kinetic method for D-3-hydroxybutyrate in plasma or serum. Clin. Chem. 30:421-425.

Miettinen, P. V. A. 1995. Prevention of bovine ketosis with glucogenic substances and its effects on fertility in Finnish dairy cows. Berl. Münch. Tierärztl. Wochenschr. 108:14-19.

Miyoshi, S., J. L. Pate, and D. L. Palmquist. 2001. Effects of propylene glycol drenching on energy balance, plasma glucose, plasma insulin, ovarian function and conception in dairy cows. Anim. Reprod. Sci. 68:29-43.

Mulder, C., J. A. Schouten, and C. Popp-Snijders. 1983. Determination of free fatty acids: A comparative study of the enzymatic versus the gas chromatographic and the colorimetric method. J. Clin. Chem. Clin. Biochem. 21:823-827.

Naessens, J., and J. Hopkins. 1996. Introduction and summary of workshop findings (The third workshop on the ruminant leukocyte antigens). Vet. Immunol. Immunopathol. 52:213-235.

Pehrson, B., K. P. Forshell, and J. Carlsson. 1992. The effect of additional feeding on the fertility of high-yielding dairy cows. J. Vet. Med. A 39:187-192.

Pickett, M. M., M. S. Piepenbrink, and T. R. Overton. 2003. Effects of propylene glycol or fat drench on plasma metabolites, liver composition, and production of dairy cows during the periparturient period. J. Dairy Sci. 86:2113-2121.

Rahmatullah, M., and T. Boyd. 1980. Improvements in the determination of urea using diacetyl monoxime methods without deproteinisation. Clin. Chem. A 107:3-9.

Rudzik L. 1981. Anmerkungen zur Bestimmung von Fett, Eiweiß und Laktose in Milch durch IR-spektroskopische Methoden. Welt der Milch. 35:1321-1324.

SAS User's Guide: Statistics. V. 6. 1991. SAS Inst., Inc., Cary, NC.

Sato, S., S. Suzuki, and K. Okada. 1995. Suppression of mitogenic response of bovine peripheral blood lymphocytes by ketone bodies. J. Vet. Med. Sci. 57:183-185.

Schneeberger, M. 1978. Der Verlauf der Laktationskurve und die Schätzung der Milchleistung beim schweizerischen Braunvieh. Eidgen. Ph.D. Diss., Techn. Hochschule Zürich.

Sevinc, M., A. Basoglu, F. Birdane, and M. Boydak. 2001. Liver function in dairy cows with fatty liver. Rev. Med. Vet. 152:297-300.

Sharma, B. K., M. J. Vandehaar, and N. K. Ames. 1994. Expression of insulin-like growth factor- 1 in cows at different stages of lactation and in late lactation cows treated with somatropin. J. Dairy Sci. 77:2232-2241.

Sommer, H. 1969. Bestimmung und physiologischer Bereich der Blutserum-Glutamat-Oxalaxcetat-Transaminase (GOT) und der Lactat-Dehydrogenase (LDH) beim Rind. Prakt. Tierärzt. $50: 451-452$

Spicer, L. J., E. Alpizar, and S. E. Echternkamp. 1993. Effects of insulin, insulin-like growth factor 1, and gonadotropins on bovine granulosa cell proliferation, progesterone production, estradiol production, and(or) insulin-like growth factor 1 production in vitro. J. Anim. Sci. 71:1232-1241.

Spicer, L. J., W. B. Tucker, and G. D. Adams. 1990. Insulin-like growth factor-1 in dairy cows: Relationships among energy balance, body 
condition, ovarian activity, and estrous behaviour. J. Dairy Sci. 73:929-937.

Steel, R. G. D., and J. H. Torrie. 1980. Principles and Procedures of Statistics. A Biometrical Approach. 2nd ed. McGraw-Hill Book Company, New York, NY.

Studer, V. A., R. R. Grummer, and S. J. Bertics. 1993. Effect of prepartum propylene glycol administration on periparturient fatty liver in dairy cows. J. Dairy Sci. 76:2931-2939.

Thissen, J. P., J. M. Ketelslegers, and L. E. Underwood. 1994. Nutritional regulation of the insulin-like growth factors. Endocrinol. Rev. 15:80-101.

Wathes, D. C., T. S. Reynolds, R. S. Robinson, and K. R. Stevenson. 1998. Role of the insulin-like growth factor system in uterine function and placental development in ruminants. J. Dairy Sci. 81:1778-1789.
Wemheuer, W. 1987. Auswertung von Blutparametern aus fruchtbarkeitsgestörten Milchviehbeständen. Tierärztl. Prax. 15:353-360

Wood, P. D. P. 1967. Algebraic model of the lactation curve in cattle. Nature 216:164-165.

Zerbe, H., O. Oßadnik, W. Leibold, and H. J. Schuberth. 2001. Influence of Escherichia coli and Arcanobacterium pyogenes isolated from bovine puerperal uteri on phenotypic and functional properties of neutrophils. Vet. Microbiol. 79:351-365.

Zerbe, H., N. Schneider, W. Leibold, T. Wensing, T. Kruip, and H. J. Schuberth. 2000. Altered functional and immunophenotypical properties of neutrophilic granulocytes in post partum cows associated with fatty liver. Theriogenology 54:771-786.

Zerbe, H., H. J. Schuberth, M. Hoedemaker, E. Grunert, and W. Leibold. 1996. A new model system for endometritis: Basic concept and characterization of phenotypic and functional properties of bovine uterine neutrophils. Theriogenology 46:1339-1356. 